\title{
Is Oncidium poikilostalix an invasive species? Population ecology and reproductive behavior of this epiphytic orchid in Chiapas, Mexico
}

\section{¿Es Oncidium poikilostalix una especie invasora? Ecología poblacional y comportamiento reproductivo de esta orquídea epífita en Chiapas, México}

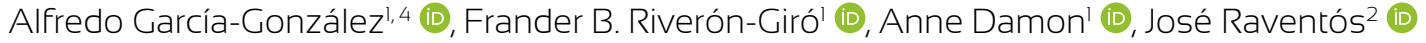 \\ Osiris Aguilar-Romero ${ }^{3}$ (1)
}

1 El Colegio de la Frontera Sur (ECOSUR), Unidad Tapachula, carretera Antiguo Aeropuerto km 2.5, 30700 Tapachula, Chiapas, México.

2 Universidad de Alicante, Departamento de Ecología, carretera de San Vicente del Raspeig s/n, 03690 Alicante, España.

3 Universidad Autónoma Metropolitana, Unidad Iztapalapa, Av. San Rafael Atlixco No. 186, Col. Vicentina, Delegación Iztapalapa, 09340 Cd. Mx., México.

4 Author for correspondence: alfredm×22@gmail.com

Received: April 5, 2018

Reviewed: May 2,2018.

Accepted: June 8, 2018

Online first: August 20, 2018

Published: October 3, 2018

To cite as:

García-González, A., F. B. Riverón-Giró, A. Damon, J. Raventós and O. Aguilar-Romero. 2018. Is Oncidium poikilostalix an invasive species? Population ecology and reproductive behavior of this epiphytic orchid in Chiapas, Mexico. Acta Botanica Mexicana 125: 215230. DOI: 10.21829/abml25.2018.1370

$\mathrm{DOl}$

$10.21829 / \mathrm{abm} 125.2018 .1370$

\section{ABSTRACT:}

Background and Aims: Biological invasions are considered as second to habitat loss as a cause of the extinction of species. The study of population dynamics is particularly relevant for species with expansive behavior. The aims of this study were to: (1) evaluate the population ecology of Oncidium poikilostalix in shaded coffee plantations in Mexico, (2) evaluate the reproductive behavior of $O$. poikilostalix in this habitat, and (3) determine whether this orchid should be considered as an invasive species.

Methods: During 2013-2015, most of the individuals of the Mexican population of O. poikilostalix (located south of the state Chiapas) were marked and measured. Additionally, the flower and fruit production (first flowering and repeated flowering), mortality and recruitment of new individuals were registered annually, and its potential distribution was modeled.

Key results: Within this period a population increase of $1.11 \%$ was observed, with a proportional increase in the number of flowers and fruits. There was a strong correlation between the leaf area of individuals and the production of flower spikes $(R=0.690, p<0.001)$ and flowers $(R=0.775, p<0.001)$. The number of mature individuals that had repeated flowering varied from $47.1 \%$ in 2013 to $22.5 \%$ in 2015 . There was also correlation between the leaf area of individuals with the fact that they do not flower, flower once and repeated flowering $\left(\mathrm{X}^{2}=277.65, \mathrm{p}<0.001\right)$. The Mexican population of $O$. poikilostalix is located on the northern limit of the potential distribution of this species.

Conclusions: It is unlikely that $O$. poikilostalix behaves as an invasive species. Despite being a locally abundant taxon, with an apparently healthy population established in traditional shaded coffee plantations, its distribution in Mexico is limited, which may represent a serious risk to its survival in the country.

Key words: conservation, demography, epiphytic orchids, flowering.

\section{Resumen:}

Antecedentes y Objetivos: Las invasiones biológicas se consideran la segunda causa de extinción de especies después de la destrucción del hábitat. Cuando se trabaja con especies con una tendencia expansiva, los estudios de dinámica poblacional son particularmente relevantes. Los objetivos de este estudio fueron: (1) evaluar la ecología poblacional de Oncidium poikilostalix en cafetales de sombra en México, (2) evaluar el comportamiento reproductivo de O. poikilostalix en este hábitat, y (3) determinar si esta orquídea se debe considerar como una especie invasora.

Métodos: Durante 2013-2015 se marcaron y midieron la mayoría de los individuos de la población mexicana de $O$. poikilostalix (localizada al sur del estado de Chiapas). Además, se registraron anualmente la producción de flores y frutos (primera floración y floración repetida), la mortalidad y el reclutamiento de nuevos individuos, y se modeló su distribución potencial.

Resultados clave: Dentro de este periodo se observó un incremento poblacional de $1.11 \%$, con un aumento proporcional en el número de flores y frutos. Existe una fuerte correlación entre el área foliar de los individuos, y la producción de espigas $(\mathrm{R}=0.690, \mathrm{p}<0.001)$ y flores $(\mathrm{R}=0.775, \mathrm{p}<0.001)$. El número de individuos adultos que tuvieron floración repetida varió de $47.1 \%$ en 2013 a 22.5\% en 2015. También se encontró correlación entre el área foliar de los individuos y el hecho de que no florezcan, florezcan una vez, o presenten floración repetida $\left(\mathrm{X}^{2}=277.65, \mathrm{p}<0.001\right)$. La población mexicana de O. poikilostalix se localiza en el límite norte de la distribución potencial de esta especie.

Conclusiones: Es poco probable que $O$. poikilostalix sea una especie invasora. A pesar de ser un taxon localmente abundante, con una población aparentemente sana establecida en cafetales tradicionales de sombra, su área de distribución en México aún es restringida, lo que puede representar un grave riesgo para su supervivencia en el país. Palabras clave: conservación, demografía, floración, orquídeas epífitas. 


\section{INTRODUCTION}

Biological invasions are considered on a global scale as second to habitat loss as a cause for the extinction of species (Lowe et al., 2004; González-Torres et al., 2012). Invasive species can cause alterations in the species composition and trophic structure of ecosystems, and /or, displacement of native species (González-Torres et al., 2012).

The IUCN (International Union for Conservation of Nature) defines invasive species as "exotic species that have been established in natural or semi-natural habitats, which are agents of change and threaten native biological diversity" (IUCN, 1999). The Global Strategy on Invasive Alien Species identifies the term as "exotic species whose establishment and expansion threaten ecosystems, habitats and other species, and that have negative economic and environmental effects" (McNeely, et al., 2001); thereby, the great importance of identifying whether a taxon has invasive behavior or not. In the case of orchids, the Global Compendium of Weeds (GCW) lists more than 90 species (Ackerman, 2007; AgWest and HEAR, 2011).

When working with species that show expansive behavior, population dynamics studies can be useful. A study of the natural dynamics of a population allows us to discover basic biological characteristics of a species by understanding the life cycle, which is fundamental to the description of a taxon (Caswell, 2001). Furthermore, through this type of study, it is possible to determine the principal factors that regulate the size of the chosen population (Harper and White, 1974; Solbrig, 1981). Population dynamics generally focus on the fluctuations of population size with time as a result of fecundity, growth and survival (Begon and Mortimer, 1981).

Shaded coffee plantations are one of the perennial agroecosystems that most resemble the conditions of the original forests, and function as refuges for numerous species of flora and fauna (Moguel and Toledo, 1999; Espejo et al., 2005; Manson et al., 2008; Leyequien and Toledo, 2009; Altamirano et al., 2011; Hágsater et al., 2015). Various studies suggest that many orchid species have found refuge in coffee plantations, as their natural habitats have become depleted and fragmented and that these plantations may also function as biological corridors between the few remaining patches of natural forest ecosystems (Solano-Gómez et al., 2011; 2016).

In Mexico, one of the epiphytic orchid species that can be found exclusively in shaded coffee plantations is Oncidium poikilostalix (Kraenzl.) M.W. Chase \& N.H. Williams (Fig. 1A, B), a taxon that was reported as a new record for the country in 2008 (García-González et al., 2011; Solano-Gómez et al., 2011). This species grows mostly on Arabica coffee shrubs (Coffea arabica L.), initially showing characteristics inherent to invasive plant species, as it was apparently competing with other epiphytic orchid species in the area (García-González et al., 2013).

Considering these facts, the aims of this study were to: (1) evaluate the population ecology of $O$. poikilostalix in shaded coffee plantations in Mexico, (2) evaluate the reproductive behavior of $O$. poikilostalix in this habitat, and (3) determine whether this orchid should be considered as an invasive species.

\section{Materials and Methods}

\section{Study site and species characteristics}

The study was carried out from 2013 to 2015, in a 20 year-old, traditional, shaded plantation of Arabica coffee (C. arabica), with a commercial polyculture system (Moguel and Toledo, 1999). The plantation is located within the rural community Fracción Montecristo, in the buffer zone of the Volcán Tacaná Biosphere Reserve, in the municipality of Cacahoatán, in the region of Soconusco, Chiapas, Mexico. The study area $\left(15^{\circ} 5^{\prime} 31.5^{\prime \prime} \mathrm{N}, 92^{\circ} 9^{\prime} 57.9^{\prime \prime} \mathrm{W}\right.$; Fig. 2) is located at an elevation of $1410 \mathrm{~m}$, with an annual rainfall of $3670 \mathrm{~mm}$ and average temperature of 20.7 ${ }^{\circ} \mathrm{C}$ (SEMARNAT and CONANP, 2013). Oncidium poikilostalix is a relatively small orchid, with basal-lateral inflorescences (1-2 per pseudobulb), and small yellow flowers with reddish-brown spots on the sepals, petals and labellum (Béhar and Tinschert, 1998; Atwood and Mora de Retana, 1999; Solano-Gómez et al., 2011). 


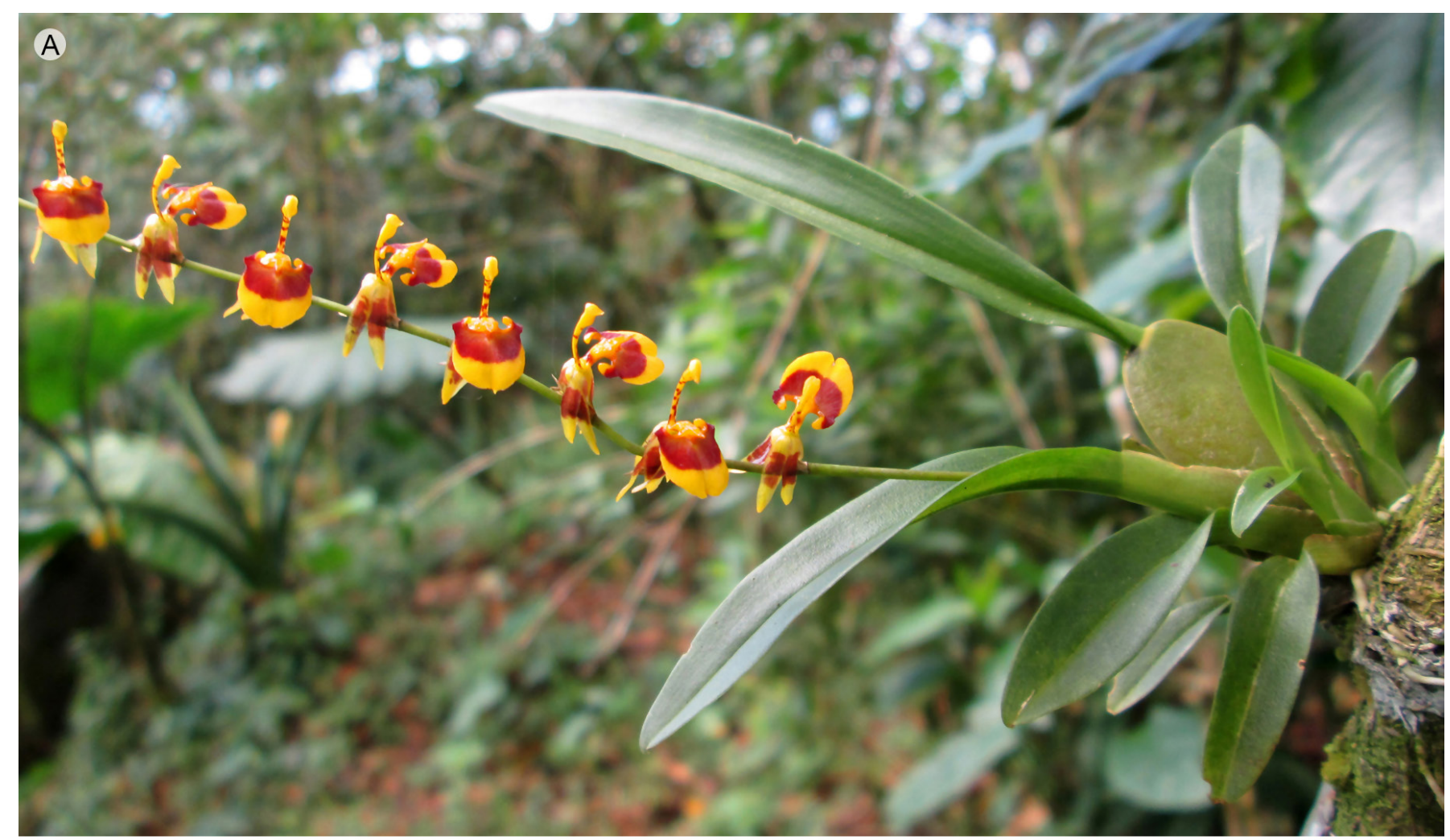

(B)

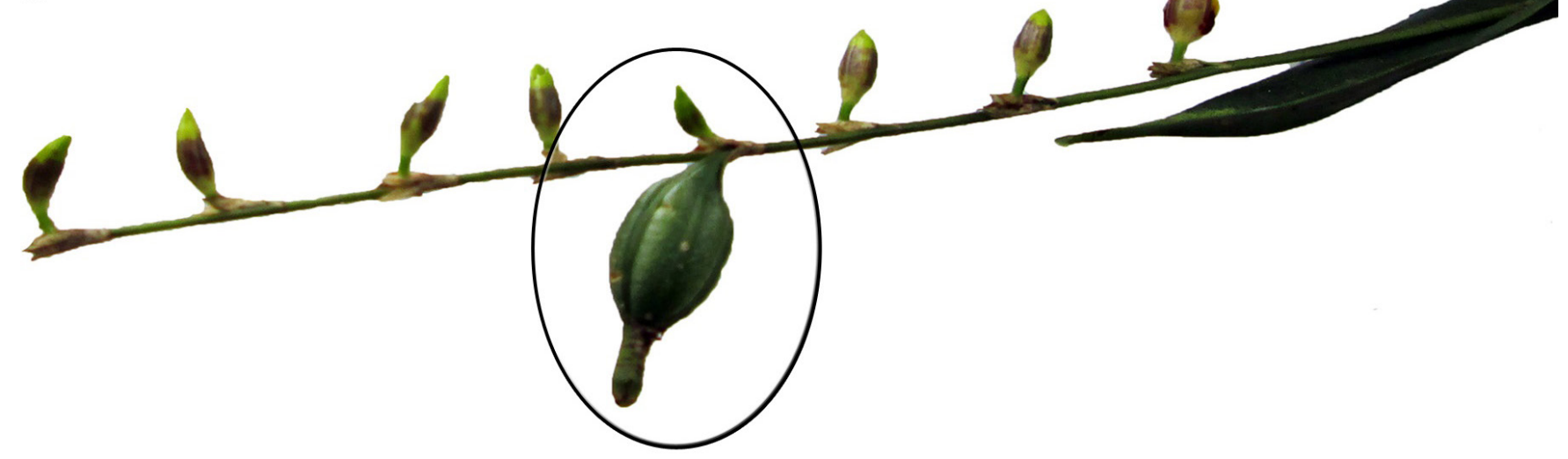

Figure 1: Oncidium poikilostalix (Kraenzl.) M.W. Chase \& N.H. Williams (Orchidaceae), A. adult individual growing in a traditional shaded coffee plantation in the region of Soconusco, Chiapas, Mexico; B. flower spike with repeated flowering, a fruit, product of the first flowering, is observed.

\section{Field study}

In the selected coffee plantation, four plots were marked

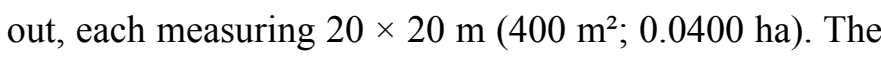
largest part of the entire population of $O$. poikilostalix found in Mexico (Solano-Gómez et al., 2011) was included within these plots.
In July 2013, each individual of $O$. poikilostalix within the four plots was marked with a small, soft, aluminum label bearing a unique number. In this study, only those individuals of $O$. poikilostalix that were growing on coffee shrubs were considered, bearing in mind that there were few individuals growing on the shade trees 


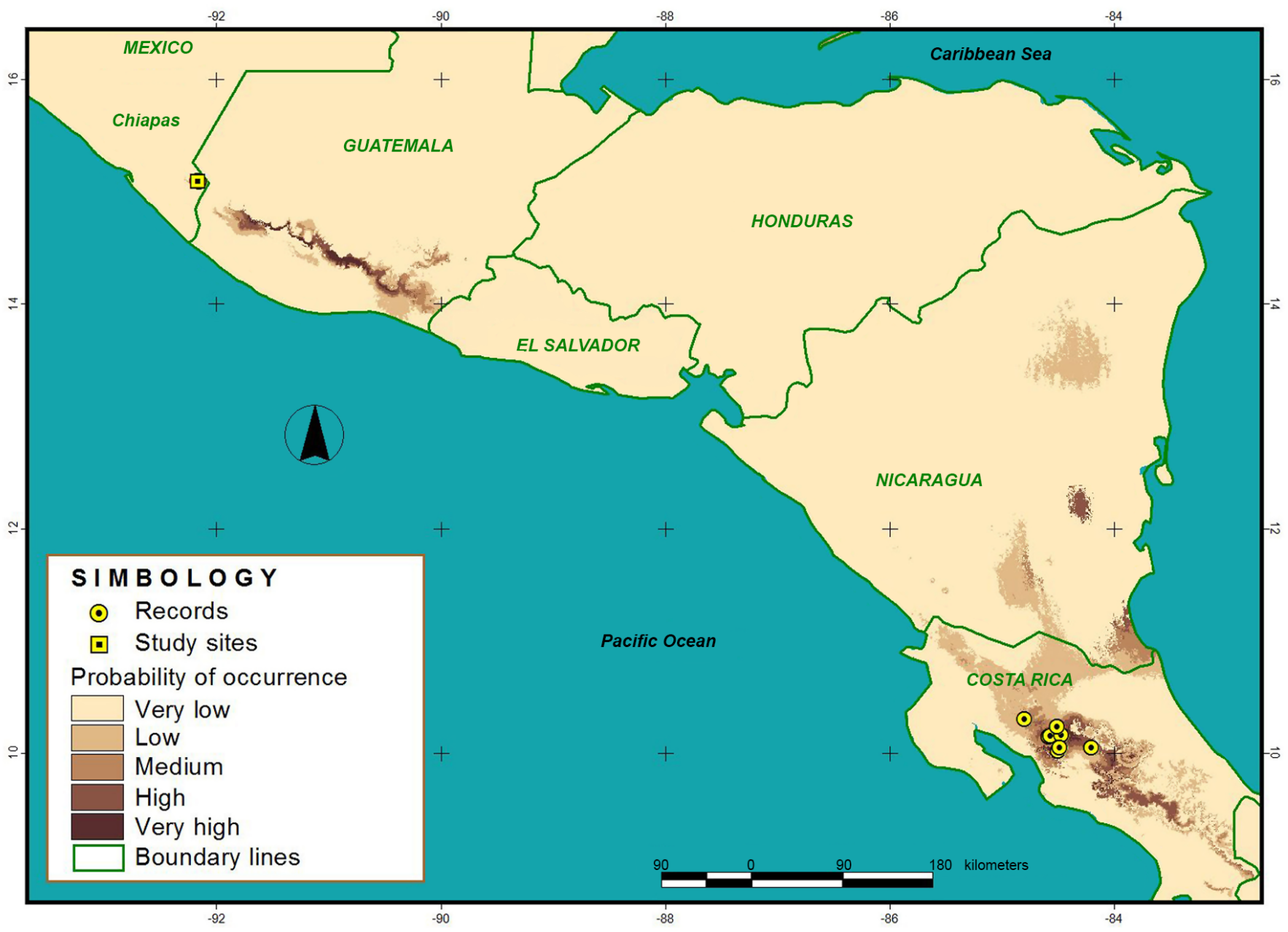

Figure 2: Oncidium poikilostalix (Kraenzl.) M.W. Chase \& N.H. Williams (Orchidaceae), records of its presence and potential distribution.

(less than 3\% of the total population) (García-González et al., 2016), and those were mostly unhealthy (chlorotic, underdeveloped pseudobulbs, small, etoliated leaves, or without leaves).

Considering that the population behavior and response to environmental stimuli of a species probably varies between life stages (seedlings, juvenile plants, mature plants) (Larson, 1992; Zotz, 1998; Zotz and Schmidt, 2006), we defined four size categories (life stages) based on leaf area: S1: $0.01-2.12 \mathrm{~cm}^{2}, \mathrm{~S} 2: 2.13-7.31 \mathrm{~cm}^{2}, \mathrm{~S} 3: 7.32-$ $22.09 \mathrm{~cm}^{2}, \mathrm{~S} 4: \geq 22.1 \mathrm{~cm}^{2}$. The $\mathrm{S} 3$ and $\mathrm{S} 4$ categories consist of mature, reproductive individuals. We measured the three largest leaves (length $\times$ width) of each individual and estimated the mean total foliar area per individual (Gregg and
Kéry, 2006; Mújica, 2008; González, 2010). We used leaf area as a state variable in all analyses because leaf area is generally a good predictor of the relative size of epiphytic orchids (Montalvo and Ackerman, 1987; Calvo, 1993; Mújica, 2008). The leaf area value obtained by this method is not a real value, but allows us to estimate the size changes through time. Each year we evaluated the status of all individuals marked in the previous year and new individuals were labeled and incorporated into the study.

During the three years of study, in October (the middle of the flowering period and the end of peak flowering; García-González et al., 2013), the number of $O$. poikilostalix individuals with repeated flowering were counted, along with the number and length of flower 
spikes with repeated flowering (Fig. 1B), per individual, the total number of flower scars per spike, the number of flower scars with repeated flowering and the number of fruits produced by those spikes as a result of the first (principal) flowering (Fig. 1B). García-González et al. (2013) defined the repeated flowering as a second flowering that is produced on the same spikes, within the same year, in which the buds develop directly from the scars left from the first set of flowers, and even where fruits are present. Finally, in December (the end of the flowering period; García-González et al., 2013), the total number of flowering individuals in the population was counted, as well as number and length of flower spikes per individual, the total number of flowers produced (including repeated flowering) and the total number of fruits produced (including repeated flowering).

\section{Potential distribution modeling of O. poikilostalix}

A potential distribution model of $O$. poikilostalix was constructed using the software MaxEnt v. 3.3.3k (Phillips et al., 2006), which is an artificial intelligence method that is based on the principle of Maximum Entropy. Its operation is based on estimating the most uniform geographical distribution throughout the study area, with the restriction that the expected value for each environmental variable agrees with its empirical value (average value of the presence data set).

The model obtained can express the value of habitat suitability for the species, where a high value in a given cell indicates that it presents very favorable conditions for the presence of the species. In addition, the program provides response curves of the species to different environmental variables, provides the values of the variables that contribute most to the model, and estimates the importance of each variable through a Jackknife test, omission errors tables, the ROC curve (Receiver Operating Characteristic), and the AUC statistic (Area Under the Curve).

For the construction of the model, 16 records of the presence of $O$. poikilostalix were used (14 in Costa Rica and two in Mexico), that were directly generated from field work, specialized literature and digital databases. We used 19 bioclimatic variables obtained from WorldClim (WorldClim, 2017) at a resolution of $1 \mathrm{~km}^{2}$, generated from the interpolation of the monthly averages of the minimum, maximum and medium temperature and precipitation of the period 1960 to 1990 (Hijmans et al., 2005). Additionally, three topographic variables (elevation, slope and slope orientation) (USGS, 2018) were used at a resolution of $1 \mathrm{~km}^{2}$. Finally, the model obtained was classified into five categories representing the probability of presence of $O$. poikilostalix.

\section{Statistical analysis}

As descriptive statistics, the mean and standard error were applied. Non-parametric statistics were used for the rest of the analyses. Relationships between the leaf area of individual and the production of flower spikes, flowers, and fruits were detected using Spearman's Rank Correlation Coefficient. To analyze different parameters and life stage data related to population dynamics and reproduction, the $\mathrm{Chi}^{2}$, Mann-Whitney U, Kruskal-Wallis and Wilcoxon tests were used. The Generalized Linear Model was used to elucidate whether there was a relationship between the leaf area of the individuals and the fact that they did not flower, flowered once, and had repeated flowering. The analyses were carried out using the programs STATISTICA (StatSoft, 2018) v. 8.0 and JMP (SAS, 2018) v. 13.2.1.

\section{RESULTS}

\section{Population dynamics of $O$. poikilostalix}

In 2013, 1036 individuals of $O$. poikilostalix were labelled (Fig. 3), and a population increase of $1.11 \%$ was observed for 2015. The number of individuals for each life stage varied during the study period (Table 1), with reproductive adults II (S4) being the most abundant life stage (Fig. 3). The number of new individuals in the population also varied (Table 1), with more new individuals recruited during the period 2013-2014 (Fig. 3). Mortality due to natural causes (pests, diseases, climatic factors) was similar for both periods (Table 1), while the mortality 
caused by traditional management practices was the same (Fig. 3). Some individuals of $O$. poikilostalix reached sexual maturity at one year or less. In the period 2013-2014, 53 individuals that were young plants in 2013 produced their first flowers in 2014 (47 S3 individuals, 6 S4 individuals), while in 2014-2015, $41 \mathrm{~S} 3$ individuals that were young plants in 2014 flowered for the first time in 2015.

\section{Reproduction}

In 2015, the highest number of flowering individuals of O. poikilostalix was registered (560 individuals; $48.61 \%$ of the population; Table 2), coinciding with the population increase (Fig. 3). The percentage of individuals that produced flowers in the three years (2013-2015) was similar. The number of flower spikes, flowers and fruits also increased (Table 2). In the case of the flower spikes, there was a significant difference between the number and length of flower spikes produced by S3 and S4 individuals (Table 1). There was a strong correlation between the leaf area of individuals and the production of flower spikes
$(\mathrm{R}=0.690, \mathrm{p}<0.001)$ and flowers $(\mathrm{R}=0.775, \mathrm{p}<0.001)$. On the other hand, correlations between the number of fruits, and the leaf area $(\mathrm{R}=0.290, \mathrm{p}<0.001)$, number of flower spikes $(\mathrm{R}=0.435, \mathrm{p}<0.001)$ and flowers $(\mathrm{R}=0.376$, $\mathrm{p}<0.001$ ), were not as strong as the mentioned before.

The total number of adult individuals that showed repeated flowering varied from $47.1 \%$ in 2013 to $22.5 \%$ in 2015 (Table 3), with differences between the S3 and S4 individuals with repeated flowering (Table 1). Repeated flowering generally occurred in individuals that flowered early (approximately June-July), leaving sufficient time for a second flowering. Of those individuals that repeated flowering in 2013, 117 (47.95\%) also had repeated flowering in 2014, whilst of those that repeated flowering in 2014, 77 (33.48\%) continued to do so in 2015. A total of 39 individuals registered repeated flowering in all three years of the study.

During the three years of study, differences were observed in the number of repeated flowering individuals that produce fruits and in the general number of flower

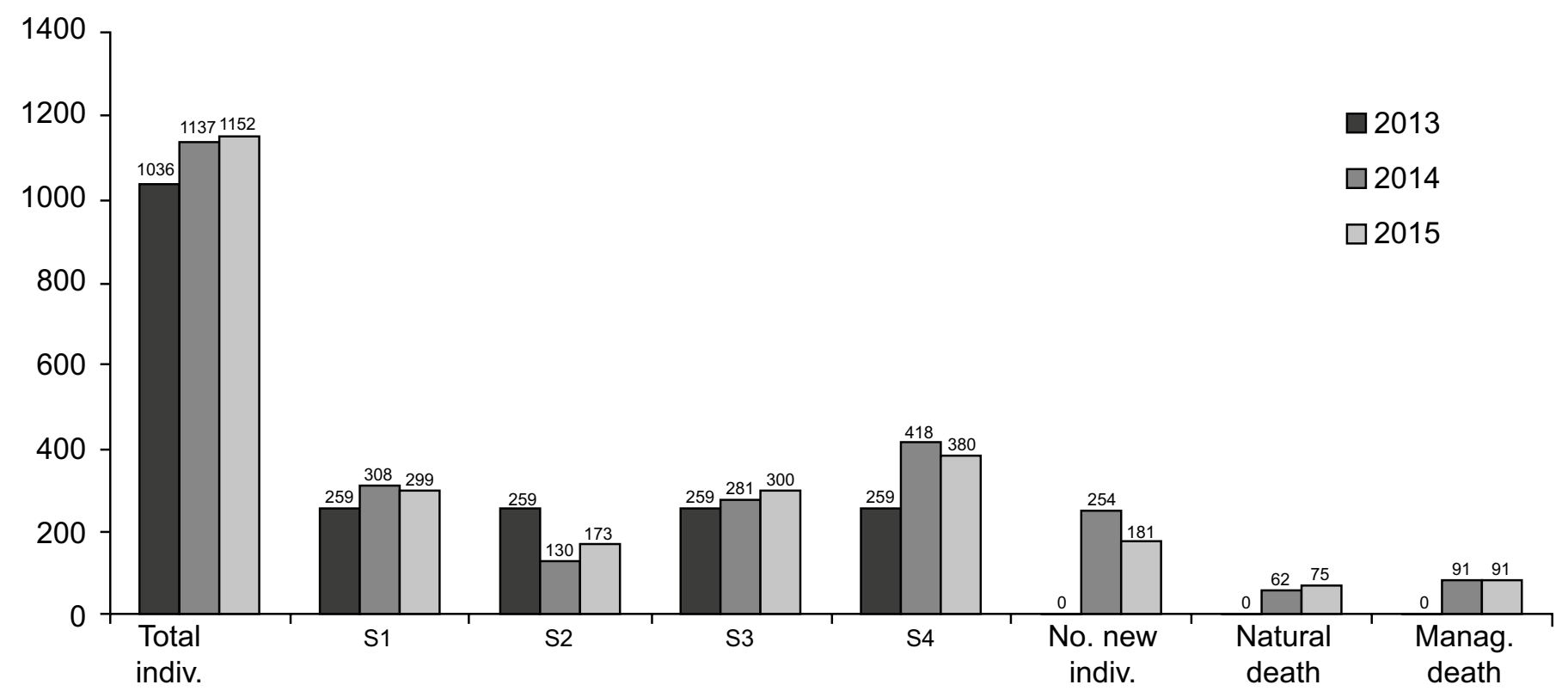

Figure 3: Oncidium poikilostalix (Kraenzl.) M.W. Chase \& N.H. Williams (Orchidaceae). Total number of individuals labelled per year (20132015) and number of individuals per life stage (young plant (S1), juvenile (S2), reproductive adult I (S3), reproductive adult II (S4)), in the population studied in the region of Soconusco, Chiapas, Mexico. Number of new individuals recruited into the population each year, and number of individuals that die per year, from natural causes (pests, diseases, climatic factors), or as a direct result of the traditional management practices of the coffee plantation. 
Table 1: Statistical analysis and parameters considered in a population of Oncidium poikilostalix (Kraenzl.) M.W. Chase \& N.H. Williams (Orchidaceae), in the region of Soconusco, Chiapas, Mexico. S3: reproductive adult I; S4: reproductive adult II. In bold, the significant results are highlighted.

Parameters and life stage data analyzed during the three-year study Statistical analysis

Population dynamic

Number of individuals per life stage, 2013, 2014 and 2015.

$\mathrm{X}^{2}=88.476, \mathrm{df}=6, \mathbf{p}<\mathbf{0 . 0 0 1}$

Number of new individuals recruited into the population during 2014 and 2015.

$\mathrm{X}^{2}=5.835, \mathrm{df}=1, \mathbf{p}=\mathbf{0 . 0 1 6}$

Number of individuals that died from natural causes (pests, diseases, climatic factors) (2013-2014 and

$\mathrm{X}^{2}=0.528, \mathrm{df}=1, \mathrm{p}=0.468$

2014-2015).

Reproduction

Total number of flower spikes, comparing S3 and S4 individuals.

$\mathrm{U}=82268, \mathrm{z}=23.500, \mathbf{p}<\mathbf{0 . 0 0 1}$

Length of flower spikes, comparing S3 and S4 individuals.

$\mathrm{U}=758827.5, \mathrm{z}=34.876, \mathbf{p}<\mathbf{0 . 0 0 1}$

Number of individuals with repeated flowering, comparing S3 and S4 individuals.

$X^{2}=253.042, \mathrm{df}=1, \mathbf{p}<\mathbf{0 . 0 0 1}$

Total number of individuals with repeated flowering that produced fruits, comparing 2013, 2014 and 2015. $\quad X^{2}=12.459, \mathrm{df}=2, \mathbf{p}=\mathbf{0 . 0 0 2}$

Number of flower spikes with repeated flowering, comparing 2013, 2014 and 2015.

$\mathrm{H}=20.022, \mathrm{df}=2, \mathbf{p}<\mathbf{0 . 0 0 1}$

Total number of flowers produced in the repeated flowering, comparing 2013, 2014 y 2015.

$\mathrm{H}=144.094, \mathrm{df}=2, \mathbf{p}<\mathbf{0 . 0 0 1}$

Total number of fruits produced in the repeated flowering, comparing 2013, 2014 y 2015.

$\mathrm{H}=2.379, \mathrm{df}=2, \mathrm{p}=0.304$

Number of flowers produced in the repeated flowering, comparing S3 and S4 individuals.

$\mathrm{U}=101051.5, \mathrm{z}=7.888, \mathbf{p}<\mathbf{0 . 0 0 1}$

Number of fruits produced in the repeated flowering, comparing S3 and S4 individuals.

$\mathrm{U}=27212.5, \mathrm{z}=2.223, \mathbf{p}=\mathbf{0 . 0 2 6}$

Total number of fruits produced by individuals, comparing the first flowering and repeated flowering.

$\mathrm{T}=1976.5, \mathrm{z}=15.415, \mathbf{p}<\mathbf{0 . 0 0 1}$

Table 2: General flowering data in reproductive adults I (S3) and II (S4) in a population of Oncidium poikilostalix (Kraenzl.) M.W. Chase \& N.H. Williams (Orchidaceae) studied in the region of Soconusco, Chiapas, Mexico, during a three year period (2013-2015) ( \pm standard error).

\begin{tabular}{|c|c|c|c|c|c|c|c|c|}
\hline Year & $\begin{array}{c}\text { Number of } \\
\text { individuals } \\
\text { that } \\
\text { flowered }\end{array}$ & $\begin{array}{c}\text { Number } \\
\text { of flower } \\
\text { spikes } \\
\text { produced }\end{array}$ & $\begin{array}{c}\text { Average } \\
\text { number of } \\
\text { flower spikes } \\
\text { produced per } \\
\text { individual }\end{array}$ & $\begin{array}{c}\text { Number } \\
\text { of flowers } \\
\text { produced } \\
\text { (including } \\
\text { repeated } \\
\text { flowering) }\end{array}$ & $\begin{array}{c}\text { Average } \\
\text { number of } \\
\text { flowers per } \\
\text { individual that } \\
\text { flowered }\end{array}$ & $\begin{array}{c}\text { Number of } \\
\text { individuals } \\
\text { that produced } \\
\text { fruits }\end{array}$ & $\begin{array}{c}\text { Number of } \\
\text { fruits produced } \\
\text { (including } \\
\text { those produced } \\
\text { in the repeated } \\
\text { flowering) }\end{array}$ & $\begin{array}{c}\text { Average } \\
\text { number of } \\
\text { fruits produced } \\
\text { per individual } \\
\text { that produced } \\
\text { fruits }\end{array}$ \\
\hline \multicolumn{9}{|c|}{ S3 individuals } \\
\hline 2013 & 184 & 346 & $1.88 \pm 0.085$ & 2979 & $16.19 \pm 0.051$ & 65 & 149 & $0.81 \pm 0.072$ \\
\hline 2014 & 181 & 299 & $1.65 \pm 0.053$ & 2563 & $14.16 \pm 0.048$ & 38 & 63 & $0.35 \pm 0.074$ \\
\hline 2015 & 221 & 433 & $1.96 \pm 0.057$ & 3312 & $14.99 \pm 0.043$ & 178 & 573 & $2.59 \pm 0.063$ \\
\hline \multicolumn{9}{|c|}{ S4 individuals } \\
\hline 2013 & 244 & 1137 & $4.66 \pm 0.108$ & 16234 & $66.53 \pm 0.033$ & 118 & 436 & $1.79 \pm 0.039$ \\
\hline 2014 & 355 & 1586 & $4.47 \pm 0.086$ & 21739 & $61.24 \pm 0.024$ & 165 & 465 & $1.31 \pm 0.035$ \\
\hline 2015 & 339 & 1725 & $5.09 \pm 0.086$ & 19687 & $58.07 \pm 0.027$ & 303 & 2767 & $8.16 \pm 0.032$ \\
\hline
\end{tabular}


Table 3: Repeated flowering data in reproductive adults I (S3) and II (S4) in a population of Oncidium poikilostalix (Kraenzl.) M.W. Chase \& N.H. Williams (Orchidaceae) studied in the region of Soconusco, Chiapas, Mexico, during a three year period (2013-2015) ( \pm standard error). Scars: marks left by the flowers from the first flowering.

\begin{tabular}{|c|c|c|c|c|c|c|c|c|c|}
\hline Year & $\begin{array}{c}\text { Number of } \\
\text { individuals } \\
\text { with } \\
\text { repeated } \\
\text { flowering }\end{array}$ & $\begin{array}{l}\text { Number } \\
\text { of flower } \\
\text { spikes with } \\
\text { repeated } \\
\text { flowering }\end{array}$ & $\begin{array}{c}\text { Average } \\
\text { number } \\
\text { of flower } \\
\text { spikes per } \\
\text { individual }\end{array}$ & $\begin{array}{l}\text { Number of } \\
\text { flower scars } \\
\text { in the spikes } \\
\text { with repeated } \\
\text { flowering }\end{array}$ & $\begin{array}{l}\text { Number of } \\
\text { flowers that } \\
\text { had repeated } \\
\text { flowering }\end{array}$ & $\begin{array}{c}\text { Average } \\
\text { number of } \\
\text { flowers per } \\
\text { individual } \\
\text { with repeated } \\
\text { flowering }\end{array}$ & $\begin{array}{l}\text { Number of } \\
\text { individuals } \\
\text { that produced } \\
\text { fruits from } \\
\text { the repeated } \\
\text { flowering }\end{array}$ & $\begin{array}{c}\text { Number } \\
\text { of fruits } \\
\text { produced by } \\
\text { the repeated } \\
\text { flowering }\end{array}$ & $\begin{array}{c}\text { Average number } \\
\text { of fruits per } \\
\text { individual that } \\
\text { produced fruits } \\
\text { in the repeated } \\
\text { flowering }\end{array}$ \\
\hline \multicolumn{10}{|c|}{ S3 individuals } \\
\hline 2013 & 60 & 108 & $1.8 \pm 0.241$ & 856 & 355 & $5.92 \pm 0.336$ & 5 & 8 & $1.6 \pm 0.400$ \\
\hline 2014 & 31 & 54 & $1.74 \pm 0.139$ & 459 & 272 & $8.77 \pm 0.411$ & 0 & 0 & 0 \\
\hline 2015 & 23 & 31 & $1.35 \pm 0.102$ & 247 & 80 & $3.48 \pm 0.360$ & 0 & 0 & 0 \\
\hline \multicolumn{10}{|c|}{ S4 individuals } \\
\hline 2013 & 184 & 669 & $3.64 \pm 0.208$ & 7490 & 3553 & $19.31 \pm 0.262$ & 17 & 29 & $1.71 \pm 0.101$ \\
\hline 2014 & 199 & 635 & $3.19 \pm 0.168$ & 7431 & 4200 & $21.11 \pm 0.229$ & 36 & 43 & $1.48 \pm 0.069$ \\
\hline 2015 & 130 & 313 & $2.41 \pm 0.148$ & 3457 & 1351 & $10.39 \pm 0.246$ & 12 & 29 & $2.42 \pm 0.219$ \\
\hline
\end{tabular}

spikes with repeated flowering (Tables 1, 3). The total number of flowers produced in the repeated flowering was greater in S4 individuals (Table 3). However, the percentage of flowering was similar for S3 and S4 life stages, considering the total number of flowers produced in the repeated flowering and the total number of scars left by the first flowering (S3: 1562 first flowers, $707 \mathrm{sec}-$ ond flowers, $45.26 \%$ of the nodes repeated flowering; S4: 18,378 first flowers, 9104 second flowers, $49.54 \%$ of the nodes repeated flowering; Table 3). The total number of flowers produced in the repeated flowering is variable between years and individuals of the S3 and S4 life stages (Table 1). Nonetheless, the number of fruits produced as a result of the second flowering is similar between years, although variable between individuals S3 and S4 (Table 1), with more fruits produced by S4 individuals (92.7\% of the fruits) (Table 3). The global numbers of fruits produced in the first and second flowering are very different (first flowering: 97.55\%; repeated flowering: $2.45 \%$ ) (Tables 1-3). A correlation exists between the leaf area of individuals and the fact that they do not flower, flower once and flower twice (Fig. 4).

\section{Potential distribution}

The model obtained has an AUC of 0.998, which reflects a high reliability and that the distribution of the species is well explained by the environmental variables used. Oncidium poikilostalix has a high probability of presence in the areas near the collection sites in Mexico (Chiapas) and Costa Rica, as well as in the southwest of Guatemala and in a small region in the east of Nicaragua (Fig. 2). The potential areas of presence of this taxon show environmental ranges similar to those localities in which there are presence records (annual average temperatures of $26.06{ }^{\circ} \mathrm{C}$ and $2970 \mathrm{~mm}$ of rainfall). The Mexican population of this orchid is located in the northern limit of the potential distribution of the species (Fig. 2). Additionally, areas with a medium to low probability of presence were identified in the northeast and south of Nicaragua, and in northern Costa Rica (Fig. 2).

\section{DISCUSSION}

Oncidium poikilostalix was studied in Mexico for the first time in 2008-2009, where 1123 individuals were registered, of which 1060 (94.39\%) were growing on coffee 


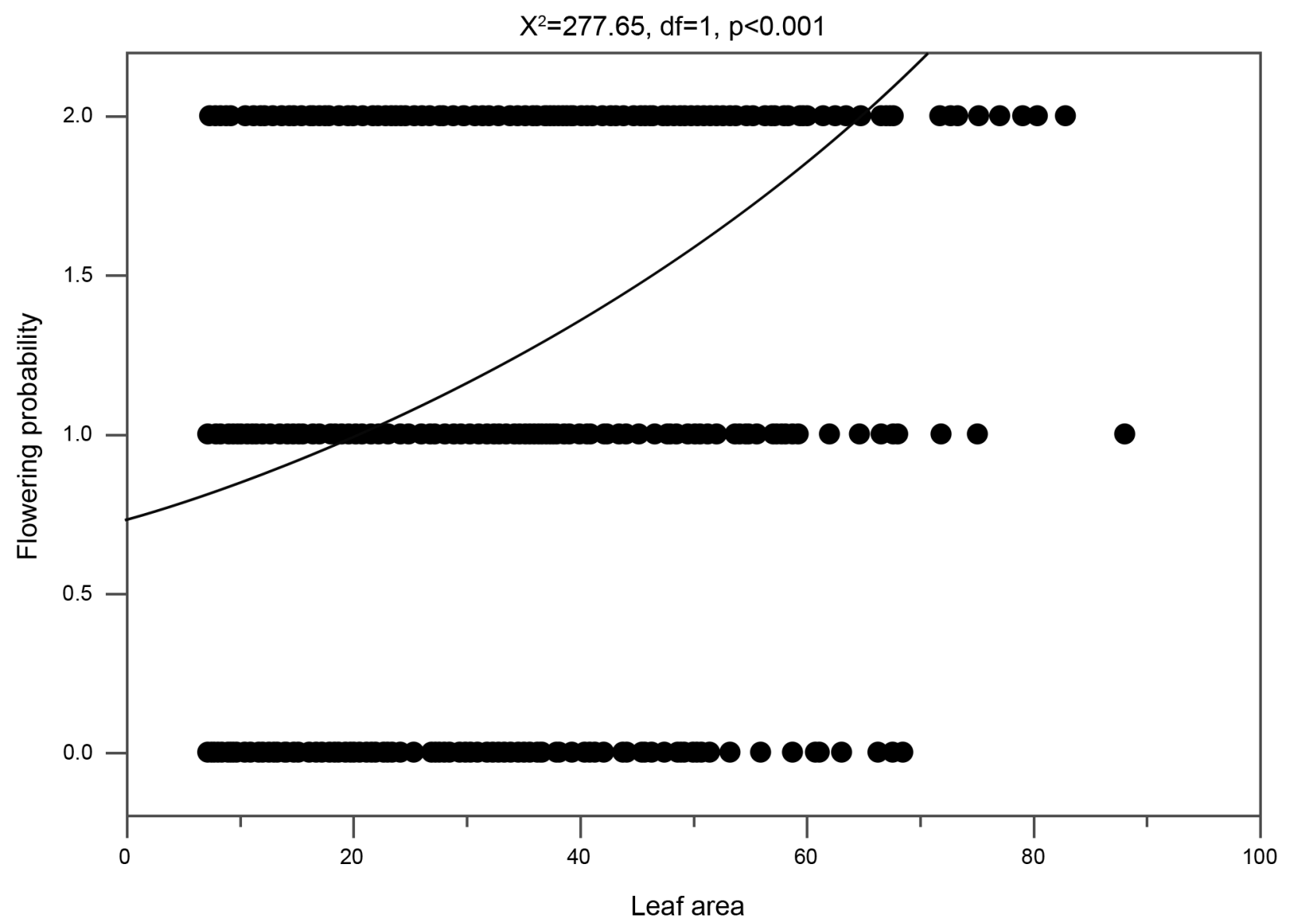

Figure 4: Oncidium poikilostalix (Kraenzl.) M.W. Chase \& N.H. Williams (Orchidaceae). Correlation (Generalized Linear Model) between the leaf area of the individuals that did not flower, flowered once, and had repeated flowering.

shrubs (García-González et al., 2011). At that time, it was considered as an invasive species, displaying a high sexual reproductive rate (García-González et al., 2013). However, to date, in Mexico O. poikilostalix has only been found in two sites separated by circa $2.5 \mathrm{~km}$, and with relatively small and concentrated populations (García-González et al., 2011; Solano-Gómez et al., 2011). Furthermore, our study shows that, although in traditional shaded coffee plantations $O$. poikilostalix can be considered a successful species and produces abundant fruits and seeds, population increase in eight years (2008-2015) probably is too slow for designation as an invasive species. In 2013, on coffee shrubs within the same study area, we found 24 less individuals than in 2008 (García-González et al., 2011), which could be due to traditional management activities or, a consequence of the natural dynamics of the population. Additionally, the hypothesis of possible competition between Oncidium poikilostalix and O. guatemalenoides M.W. Chase \& N.H. Williams (threatened species in the NOM-059-SEMARNAT-2010 (SEMARNAT, 2010); proposed by García-González et al. (2013) could not be confirmed nor rejected in this study. To do so, it would be necessary to study the population dynamics of $O$. guatemalenoides, compare the reproductive capacities, pollinators and mycorrhizal associations of both species, being important limiting factors for reproduction, germination and establishment of most orchids (Ackerman and Montalvo, 1990; Jersáková and Malinová, 2007; Damon and Valle-Mora, 2008; Hágsater et al., 2015). It should also be taken into account that, like many orchids, 
O. guatemalenoides is a naturally scarce species, with small isolated populations (Soto-Arenas and Solano-Gómez, 2007). García-González et al. (2016) found in the study area 35 individuals of $O$. guatemalenoides that were living sympatrically with $O$. poikilostalix and were apparently healthy.

As for the life stages, there was abundant recruitment of new plants; in 2013-2014 and 2014-2015, on average 1.39 and 0.89 new plants were produced for every reproductive individual that produced fruits in 2013 and 2014, respectively. During the three-year study period, between 50\% (2013) and 61.48\% (2014) of the individuals were adult, compared to only $29.91 \%$ in 2008 (GarcíaGonzález et al., 2011). The data indicate that this population of $O$. poikilostalix is mature and dynamic, with a healthy rate of recruitment and replacement, and the high proportion of mature individuals would be influential in the reproduction and expansion of the species, being the most important life stage for orchids (Zotz, 1998; Winkler and Hietz, 2001; Mondragón, 2009).

It is possible that some of the new young plants found had germinated from seeds from plants outside the study population, although the greater part of the population in this site was included in the study. It is also possible that some of those young plants were simply overlooked during the first census. Some of the new plants could have originated from seeds from the same population, but that had remained latent for more than one year; however, for epiphytic orchids little is known about seed latency or the first, microscopic stages of in situ germination (Raventós et al., 2015). We do know, however, that the seeds of the majority of orchids (including $O$. poikilostalix) are dispersed by air, and can be carried great distances (Arditti and Abdul Ghani, 2000; Hágsater et al., 2015), although most fall close to the mother plant (Machon et al., 2003; Trapnell et al., 2004; Jersáková and Malinová, 2007; Winkler et al., 2009; Chung et al., 2011).

Supporting observations made by García-González et al. (2011), under the prevailing conditions of traditional management in the coffee plantation studied, mortality of O. poikilostalix, both by natural causes (pests, diseases, climatic factors) or directly due to management activities, had no impact upon population equilibrium. In the periods 2013-2014 and 2014-2015, for every plant that died, 1.66 and 1.09 new young plants were recruited, respectively.

Typically, epiphytic orchids tend to grow and mature slowly (Hernández-Apolinar, 1992; Larson, 1992; Zotz, 1998; Winkler and Hietz, 2001; Schmidt and Zotz, 2002); however, $O$. poikilostalix does not conform to that standard. During the period 2013-2014, 20.46\% of O. poikilostalix individuals classified as young plants in 2013 reached maturity in 2014, while for 2014-2015, the value was $13.31 \%$. Hágsater et al. (2015) commented that little is known about the biology of twig epiphytes, but that within this group, precocious maturity (from a few months to one year after germination) and short generation times (1-5 years) have been observed, being phenomena that are rare for others epiphytic orchids. For example, average life expectancy for the twig epiphyte Tolumnia variegata (Sw.) Braem is only 2.7 years (Meléndez and Ackerman, 1993), while, Erycina pusilla (L.) N.H. Williams \& M.W. Chase, E. crista-galli (Rchb. f.) N.H. Williams \& M.W. Chase, and possibly Ionopsis utricularioides (Sw.) Lindl., are species capable of germinating and flowering within one year (Mondragón et al., 2007; Hágsater et al., 2015).

In Mexico, O. poikilostalix is a species with elevated percentages of flowering individuals, with values of between $76.68 \%$ and $82.63 \%$ in this study, and between $95.86 \%$ and $99.53 \%$ reported by García-González et al. (2013). Telipogon helleri (L.O. Williams) N.H. Williams $\&$ Dressler is another twig epiphyte that grows in shaded coffee plantations in the Soconusco region, and at $97.78 \%$, has a similarly high percentage of flowering individuals (García-González and Damon, 2013). The length and number of flowers produced by flower spikes of $O$. poikilostalix are directly proportional to the size of the individual. In other epiphytic orchid species, it has also been observed that the largest most vigorous individuals are those that produce the most and the largest reproductive structures (Solís-Montero et al., 2005).

The production of fruits was variable across the three-year study period. In 2013, 2014 and 2015, 42.76\%, 
$37.87 \%$ and $85.89 \%$ of the flowering plants produced fruits, respectively. The values obtained in this study for percentage of pollination (relation between the number of flowers produced and the number of fruits obtained) are similar to those reported by García-González et al. (2013) for O. poikilostalix. In 2013 and 2014, 3.04\% and 2.17\% of the flowers were pollinated and thus produced fruits, whereas in $2015,14.52 \%$ of the flowers were pollinated. These percentages do not agree with the values reported as typical for tropical orchids that produce nectar by Neiland and Wilcock (1998), being lower in 2013 and 2014 and higher in 2015 . The unusually high percentage of pollination in 2015 could have occurred as a consequence of a natural peak in flowering and fruiting, which occasionally occurs due to coinciding factors, such as temperature, humidity, winds, etc., which are favorable to the plant, the pollinator, or both. The literature includes data for other miniature species of twig epiphytic orchids that also grow on coffee shrubs in Soconusco coffee plantations, for example Telipogon helleri with $23.76 \%$ pollination (García-González and Damon, 2013), and a study of the pollination of Notylia barkeri Lindl. and E. crista-galli, carried out in two phases, gave $1.23 \%$ and $1.48 \%$ pollination (Damon and Valle-Mora, 2008) and three years later 4.9 and 4.4\%, respectively (Pérez-Hernández et al., 2011). This is also an example of how coincident environmental factors can affect pollination rates, and in this case, cause a similar increase in two different species. In shaded coffee plantations in Veracruz, percentage of pollination of the miniature orchid Scaphyglottis livida (Lindl.) Schltr. and the larger species Maxillaria densa Lindl. was 35.5\% and 18.2\%, respectively (Solís-Montero et al., 2005). Generally, the growth of populations of epiphytic orchids depends upon fruit production (Ackerman et al., 1996), but fruit production is limited by a variety of factors that may not be mutually exclusive or immediately evident, such as a lack or scarcity of pollinators, herbivory and/ or limited resources (water, nutrients, mycorrhizal fungi) available for the mother plant (Ackerman and Montalvo, 1990; Rathcke, 2001; Tremblay et al., 2005; Jersáková et al., 2006). It has been observed that orchids that produce nectar tend towards higher percentage of pollination than those that do not (Ackerman et al., 1994; Neiland and Wilcock, 1998; Smithson and Gigord, 2001); although it is likely that $O$. poikilostalix does not produce nectar, it does offer a reward of oil for its pollinators (Dressler, 1993), which could function in a similar manner.

The pollinator of $O$. poikilostalix is not known. García-González et al. (2013) found that in the studied region the species is visited by the small bee Trigona fulviventris Guérin-Meneville, but they were not seen while removing the pollinaria. Besides, it is known that these insects frequently behave as a robber of nectar and/or pollen, interfering with or competing with legitimate pollinators (Reyes-Novelo, 2004).

The phenomenon of repeated flowering in $O$. poikilostalix had been registered by García-González et al. (2013), and is uncommon within the orchid family. It is necessary to analyze the anatomical characteristics of the flower spikes of this orchid, and the physiology behind the repeated flowering, in order to understand this phenomenon. Probably, the floral buds develop from axillary buds subtended by inflorescence bracts, and not exactly from the scars of the first flowering episode, as was suggested by García-González et al. (2013).

As a result of this study we can confirm that repeated flowering in O. poikilostalix occurs regularly in this population, mainly involving the largest individuals with the greatest leaf area, and that the phenomenon was also observed in O. guatemalenoides, a coexisting, morphologically similar species (Soto-Arenas and Solano-Gómez, 2007; Solano-Gómez et al., 2011). Observations in the field suggest that a few flower spikes, in the largest individuals, may even repeat flowering three times, although it was not possible to confirm the extent to which this occurs. Repeated flowering, using the same flower spikes benefits the plant by extending the life of the flower structure increasing the likelihood of pollination (Castro et al., 2008), and is a more efficient use of the investment of possibly limited resources in the development of flower structures (García-González et al., 2013). Nonetheless, the number of fruits derived from the second 
flowering was low compared to the first flowering with a maximum of $8.14 \%$ in 2014 , and minimum of $0.87 \%$ in 2015, of the total fruits produced by all the adult individuals within the population per year. If the number of fruits produced in second flowering is analyzed, but only including within the analysis adult individuals that had repeated flowering and produced fruits (not all the adult individuals with repeated flowering produced fruits), the percentages oscillate between $13.15 \%$ in 2014 and $2.57 \%$ in 2015. Repeated flowering is maybe a recent and unconsolidated adaptation in the evolution of $O$. poikilostalix. The individuals with repeated flowering possibly use the major part of their nutrient reserves during the first flowering and are then unable to support the fruits produced during second flowering. Furthermore, although the flowers look identical to those of the first flowering (GarcíaGonzález et al., 2013), it is possible that flowers formed during the repeated flowering suffer from some kind of physiological or structural disadvantage or deformity, or will be of a size not appropriate for the pollinators. These hypotheses need to be tested by further studies.

Despite the fact that $O$. poikilostalix continues to be locally abundant and with an apparently healthy population, its distribution in Mexico remains confined to the study area. In eight years, since its arrival in Mexico in 2008 approximately (García-González et al., 2011; Solano-Gómez et al., 2011) until completion of the study in 2015 , the species did not significantly expand its distribution area in the country. Moreover, it is important to consider the bordering location of the Mexican population of $O$. poikilostalix (on the northern limit of its potential distribution), which is separated and relatively far from the closest continuous block of potential distribution of the species, located in Guatemala. Apparently, for the moment this Mexican region meets the right conditions for the development of $O$. poikilostalix. Probably, before the arrival of this species in the coffee plantations of southern Chiapas, the biotic, microclimatic and/or environmental factors suitable for the development of this plant did not exist, and the variation in the prevailing conditions may be related to climate change. However, long-term studies focused on this particular issue are essential, to be able to ensure this fact with certainty. In addition, despite the adequate environmental conditions existing for the species in this area, it must be considered that the survival of $O$. poikilostalix in Mexico is seriously threatened, as a consequence of different intensive management activities that are becoming generalized in shade coffee plantations of the Soconusco region (García-González et al., 2017).

Taking into account the current data, a reevaluation of the O. poikilostalix status in Mexico is justified, having been considered erroneously as an invasive species by García-González et al. (2013). Oncidium poikilostalix should be treated as a species that shows "range expansion", which is the process by which species (both native and exotic) expand to new areas (usually new regions, rather than movements at local scale) as a result of natural or mediated by human dispersions, mainly in areas modified by anthropic action (Richardson et al., 2011). In addition, the success of plants in today's world basically depends on having characteristics that allow them to exploit the increasingly anthropized and eutrophic landscape (Thompson and Davis, 2011). The information obtained with this investigation could be used for the elaboration and implementation of programs for the management and conservation of biodiversity in coffee plantations.

\section{AUTHOR CONTRIBUTIONS}

All the authors contributed equally in the elaboration of this work, except for the field work, which was carried out entirely by the first two authors.

\section{FUNDING}

This work was funded by the National Council for Science and Technology (CONACYT), Mexico, and El Colegio de la Frontera Sur (ECOSUR). The organization IDEA WILD provided the necessary equipment.

\section{ACINOWLEDGEMENTS}

To Nelson Pérez Miguel, for invaluable help with the field work. To the coffee producers of the Fracción Montecristo community for allowing us access to their plantations. 


\section{LITERATURE CITED}

Ackerman, J. D. 2007. Invasive orchids: weeds we hate to love? Lankesteriana 7(1-2): 19-21. DOI: https://doi. org/10.15517/lank.v7i1-2.18386

Ackerman, J. D. and A. M. Montalvo. 1990. Short- and long-term limitations to fruit production in a tropical orchid. Ecology 71(1): 263-271. DOI: https://doi. org/10.2307/1940265

Ackerman, J. D., J. A. Rodríguez-Robles and E. J. Melendez. 1994. A meager nectar offering by an epiphytic orchid is better than nothing. Biotropica 26(1): 44-49. DOI: https:// doi.org/10.2307/2389109

Ackerman, J. D., A. Sabat and J. K. Zimmerman. 1996. Seedling establishment in an epiphytic orchid: an experimental study of seed limitation. Oecologia 106(2): 192-196. DOI: https://doi.org/10.1007/bf00328598

AgWest and HEAR. 2011. Global Compendium of Weeds (GCW). Data \& weed expertise (AgWest) and the Hawaiian Ecosystems at Risk project (HEAR). http:// www.hear.org/gcw/index.html (consulted May, 2018).

Altamirano, M. A., P. L. Enríquez, J. L. Rangel, C. García and C. Tejeda. 2011. La ruta del café y la diversidad de las aves. Biodiversitas 96: 11-16.

Arditti, J. and A. K. Abdul Ghani. 2000. Tansley Review No. 110. Numerical and physical properties of orchid seeds and their biological implications. New Phytologist 145(3): 367-421. DOI: https://doi.org/10.1046/j.1469-8137.2000.00587.x

Atwood, J. T. and D. E. Mora de Retana. 1999. Family No. 39 Orchidaceae: Tribe Maxillarieae: subtribes Maxillariinae and Oncidiinae. Fieldiana Botany 40: 1-82.

Begon, M. and M. Mortimer. 1981. Population ecology: A unified study of animals and plants. Blackwell Science. Oxford, UK. 200 pp.

Béhar, M. and O. Tinschert. 1998. Guatemala y sus orquídeas. Bancafé. Guatemala, Guatemala. 240 pp.

Calvo, R. N. 1993. Evolutionary demography of orchids: Intensity and frequency of pollination and the cost of fruiting. Ecology 74(4): 1033-1042. DOI: https://doi. org/10.2307/1940473

Castro, S., P. Silveira and L. Navarro. 2008. Effect of pollination on floral longevity and costs of delaying fertilization in the outcrossing Polygala vayredae Costa (Polygalaceae). Annals of Botany 102(6): 1043-1048. DOI: https://doi. org/10.1093/aob/mcn184

Caswell, H. 2001. Matrix population models. 2nd. ed. Sinauer Associates. Massachusetts, USA. 722 pp.

Chung, M. Y., J. D. Nason and M. G. Chung. 2011. Significant demographic and fine-scale genetic structure in expanding and senescing populations of the terrestrial orchid Cymbidium goeringii (Orchidaceae). American Journal of Botany 98(12): 2027-2039. DOI: https://doi.org/10.3732/ ajb.1100094

Damon, A. and J. Valle-Mora. 2008. Retrospective spatial analysis of the pollination of two miniature epiphytic orchids with different pollination strategies in a coffee plantation in Soconusco, Chiapas, Mexico. Botanical Journal of the Linnean Society 158(3): 448-459. DOI: https://doi.org/10.1111/j.1095-8339.2008.00857.x

Dressler, R. L. 1993. Phylogeny and classification of the orchid family. Dioscorides Press. Portland, USA. 330 pp.

Espejo, A., A. R. López-Ferrari, R. Jiménez and L. Sánchez. 2005. Las orquídeas de los cafetales en México: una opción para el uso sostenible de ecosistemas tropicales. Revista de Biología Tropical 53(1-2): 73-84.

García-González, A. and A. Damon. 2013. Abundancia, distribución en los forófitos y producción de frutos de la primera población de Telipogon helleri (Orchidaceae) descubierta en México. Revista Mexicana de Biodiversidad 84(3): 894-900. DOI: https://doi.org/10.7550/rmb.33703

García-González, A., A. Damon, L. G. Esparza and J. Valle-Mora. 2011. Population structure of Oncidium poikilostalix (Orchidaceae), in coffee plantations in Soconusco, Chiapas, Mexico. Lankesteriana 11(1): 2332. DOI: https://doi.org/10.15517/lank.v11i1.18312

García-González, A., A. Damon, F. A. Iturbide and V. OlaldePortugal. 2013. Reproduction of Oncidium poikilostalix (Orchidaceae), potentially invading coffee plantations in Soconusco, Chiapas, Mexico. Plant Ecology and Evolution 146(1): 36-44. DOI: https://doi.org/10.5091/ plecevo.2013.674

García-González, A., A. Damon, J. Raventós, F. B. RiverónGiró, E. Mújica and L. Solís-Montero. 2017. Impact 
of different shade coffee management scenarios, on a population of Oncidium poikilostalix (Orchidaceae), in Soconusco, Chiapas, Mexico. Plant Ecology and Diversity 10(2-3): 185-196. DOI: https://doi.org/10.1080/17550874 .2017 .1315840

García-González, A., A. Damon, F. B. Riverón-Giró and I. Ávila-Díaz. 2016. Circular distribution of three species of epiphytic orchids in shade coffee plantations, in Soconusco, Chiapas, Mexico. Plant Ecology and Evolution 149(2): 189-198. DOI: https://doi.org/10.5091/ plecevo.2016.1150

González, E. 2010. Dinámica de las poblaciones estructuradas en clases de vida de dos especies de la familia Orchidaceae: Broughtonia cubensis (Lindley) Cogniaux y Dendrophylax lindenii (Lindley) Bentham ex Rolfe, en el Cabo San Antonio, Península de Guanahacabibes, Cuba. Modelos matriciales de proyección lineal. Tesis de doctorado. Universidad de Alicante. Alicante, España. 119 pp.

González-Torres, L. R., R. Rankin and A. Palmarola (eds.). 2012. Plantas invasoras en Cuba. Bissea 6(special issue 1): 1-137.

Gregg, K. B. and M. Kéry. 2006. Comparison of size vs. life-state classification in demographic models for the terrestrial orchid Cleistes bifaria. Biological Conservation 129(1): 50-58. DOI: https://doi.org/10.1016/j.biocon.2005.09.044

Hágsater, E., M. A. Soto, G. A. Salazar, R. Jiménez, M. A. López and R. L. Dressler. 2015. Las orquídeas de México. 2nd. ed. Instituto Chinoín. Cd. Mx., México. 304 pp.

Harper, J. L. and J. White. 1974. The demography of plants. Annual Review of Ecology and Systematics 5: 419-463. DOI: https://doi.org/10.1146/annurev. es. 05.110174 .002223

Hernández-Apolinar, M. 1992. Dinámica poblacional de Laelia speciosa (H.B.K.) Schltr. (Orchidaceae). Tesis de licenciatura. Universidad Nacional Autónoma de México (UNAM). Cd. Mx., México. 86 pp.

Hijmans, R. J., S. E. Cameron, J. L. Parra, P. G. Jones and A. Jarvis. 2005. Very high resolution interpolated climate surfaces for global land areas. International Journal of Climatology 25(15): 1965-1978. DOI: https://doi. org/10.1002/joc. 1276
IUCN. 1999. IUCN guidelines for the prevention of biodiversity loss due to biological invasion. International Union for the Conservation of Nature. Species 31/32: 28-42.

Jersáková, J. and T. Malinová. 2007. Spatial aspects of seed dispersal and seedling recruitment in orchids. New Phytologist 176(2): 237-240. DOI: https://doi. org/10.1111/j.1469-8137.2007.02223.x

Jersáková, J., S. D. Johnson and P. Kindlmann. 2006. Mechanisms and evolution of deceptive pollination in orchids. Biological Reviews 81(2): 219-235. DOI: https:// doi.org/10.1017/S1464793105006986

Larson, R. J. 1992. Population dynamics of Encyclia tampensis in Florida. Selbyana 13: 50-56.

Leyequien, E. and V. M. Toledo. 2009. Floras y aves de cafetales: Ensambles de biodiversidad en paisajes humanizados. Biodiversitas 83: 7-10.

Lowe, S., M. Browne, S. Boudjelas and M. De Poorter. 2004. 100 de las especies exóticas invasoras más dañinas del mundo. Una selección del Global Invasive Species Database. Global Invasive Species Programme (GISP), International Union for Conservation of Nature (IUCN). Auckland, New Zealand. 11 pp.

Machon, N., P. Bardin, S. J. Mazer, J. Moret, B. Godelle and F. Austerlitz. 2003. Relationship between genetic structure, and seed and pollen dispersal, in the endangered orchid Spiranthes spiralis. New Phytologist 157(3): 677-687. DOI: https://doi.org/10.1046/j.1469-8137.2003.00694.x

Manson, R. H., A. Contreras and F. López-Barrera. 2008. Estudios de la biodiversidad en cafetales. In: Manson, R. H., V. Hernández-Ortiz, S. Gallina and K. Mehltreter (eds.). Agroecosistemas cafetaleros de Veracruz: biodiversidad, manejo y conservación. Instituto de Ecología, A.C. (INECOL), Instituto Nacional de Ecología (INE)-Secretaría de Medio Ambiente y Recursos Naturales (SEMARNAT). Cd. Mx., México. Pp. 1-14.

McNeely, J. A., H. A. Mooney, L. E. Neville, P. Schei and J. K. Waage (eds.). 2001. Estrategia mundial sobre especies exóticas invasoras. Global Invasive Species Programme (GISP). International Union for the Conservation of Nature (IUCN). Gland, Suiza and Cambridge, UK. 55 pp. 
Meléndez, E. J. and J. D. Ackerman. 1993. The effects of a rust infection on fitness components in a natural population of Tolumnia variegata (Orchidaceae). Oecologia 94(3): 361367. DOI: https://doi.org/10.1007/BF00317110

Moguel, P. and V. M. Toledo. 1999. Biodiversity conservation in traditional coffee systems of Mexico. Conservation Biology 13(1): 11-21. DOI: https://doi.org/10.1046/ j.1523-1739.1999.97153.x

Mondragón, D. 2009. Population viability analysis for Guarianthe aurantiaca, an ornamental epiphytic orchid harvested in Southeast Mexico. Plant Species Biology 24(1): 35-41. DOI: https://doi.org/10.1111/j.14421984.2009.00230.x

Mondragón, D., C. Maldonado and R. Aguilar-Santelises. 2007. Life history and demography of a twig epiphyte: A case study of Erycina crista-galli (Orchidaceae). Selbyana 28(2): 137-144.

Montalvo, A. M. and J. D. Ackerman. 1987. Limitations to fruit production in Ionopsis utricularioides (Orchidaceae). Biotropica 19(1): 24-31.

Mújica, E. 2008. Ecología de las orquídeas epífitas Broughtonia cubensis (Lindley) Cogniaux, Dendrophylax lindenii (Lindley) Bentham et Rolfe y Encyclia bocourtii Mújica et Pupulin en el Cabo San Antonio, Península de Guanahacabibes, Cuba. Análisis espacio-temporal e implicaciones del impacto de un fenómeno atmosférico severo. Tesis de doctorado. Universidad de Alicante. Alicante, España. 302 pp.

Neiland, M. R. and C. Wilcock. 1998. Fruit set, nectar reward, and rarity in the Orchidaceae. American Journal of Botany 85(12): 1675-1671. DOI: https://doi. org/10.2307/2446499

Pérez-Hernández, H., A. Damon, J. Valle-Mora and D. Sánchez-Guillen. 2011. Orchid pollination: specialization in chance? Botanical Journal of the Linnaean Society 165(3): 251-266. DOI: https://doi.org/10.1111/j.10958339.2010.01109.x

Phillips, S. J., R. P. Anderson and R. E. Schapire. 2006. Maximum entropy modeling of species geographic distributions. Ecological Modelling 190(3-4): 231-259. DOI: https://doi.org/10.1016/j.ecolmodel.2005.03.026
Rathcke, B. J. 2001. Pollination and predation limit fruit set in a shrub, Bourreria succulenta (Boraginaceae), after hurricanes on San Salvador Island, Bahamas. Biotropica 33(2): 330-338. DOI: https://doi. org/10.1111/j.1744-7429.2001.tb00184.x

Raventós, J., E. González, E. Mújica and D. F. Doak. 2015. Population viability analysis of the epiphytic ghost orchid (Dendrophylax lindenii) in Cuba. Biotropica 47(2): 179189. DOI: https://doi.org/10.1111/btp.12202

Reyes-Novelo, E. 2004. Fauna de abejas silvestres (Hymenoptera: Apoidea). In: García-Aldrete, A. N. and R. Ayala (eds.). Artrópodos de Chamela. Instituto de Biología, Universidad Nacional Autónoma de México (UNAM). Cd. Mx., México. Pp. 193-219.

Richardson, D. M., P. Pyšek and J. T. Carlton. 2011. A compendium of essential concepts and terminology in invasion ecology. In: Richardson, D. M. (ed.). Fifty years of invasion ecology: The legacy of Charles Elton. WileyBlackwell. Oxford, UK. Pp. 409-420.

SAS. 2018. JMP Statistical Discovery. SAS Institute Inc. http:// www.jmp.com/es/ (consulted May, 2018).

Schmidt, G. and G. Zotz. 2002. Inherently slow growth in two Caribbean epiphytic species: a demographic approach. Journal of Vegetation Science 13(4): 527-534. DOI: https://doi.org/10.1111/j.1654-1103.2002.tb02079.x

SEMARNAT. 2010. Norma Oficial Mexicana NOM-059SEMARNAT-2010. Protección ambiental-Especies nativas de México de flora y fauna silvestres-Categorías de riesgo y especificaciones para su inclusión, exclusión o cambio-Lista de especies en riesgo. Secretaría de Medio Ambiente y Recursos Naturales. Diario Oficial de la Federación, 2nd. ed. Cd. Mx., México. http://www. profepa.gob.mx/innovaportal/file/435/1/NOM_059_ SEMARNAT_2010.pdf

SEMARNAT and CONANP. 2013. Programa de Manejo Reserva de la Biosfera Volcán Tacaná. Secretaría de Medio Ambiente y Recursos Naturales, Comisión Nacional de Áreas Naturales Protegidas. Cd. Mx., México. Pp. 208.

Smithson, A. and L. D. B. Gigord. 2001. Are there fitness advantages in being a rewardless orchid? Reward supplementation experiments with Barlia robertiana. 
Proceedings of the Royal Society B, Biological Sciences 268(1475): 1435-1441. DOI: https://doi.org/10.1098/ rspb.2001.1705

Solano-Gómez, R., A. Damon, G. Cruz-Lustre, L. JiménezBautista, S. Avendaño-Vázquez, V. Bertolini, R. Rivera-García and G. Cruz-García. 2016. Diversity and distribution of the orchids of the Tacaná-Boquerón region, Chiapas, Mexico. Botanical Sciences 94(3): 625656. DOI: https://dx.doi.org/10.17129/botsci.589

Solano-Gómez, R., R. Jiménez and A. Damon. 2011. Two new records and one rediscovery for Orchidaceae of Mexico. Acta Botanica Mexicana 96: 59-72. DOI: https://doi. org/10.21829/abm96.2011.259

Solbrig, O. T. 1981. Studies on the population biology of the genus Viola. II. The effect of plant size on fitness in Viola sororia. Evolution 35(6): 1080-1093. DOI: https://doi. org/10.1111/j.1558-5646.1981.tb04977.x

Solís-Montero, L., A. Flores-Palacios and A. Cruz-Angón. 2005. Shade-coffee plantations as refuges for tropical wild orchids in Central Veracruz, Mexico. Conservation Biology 19(3): 908-916. DOI: https://doi.org/10.1111/ j.1523-1739.2005.00482.x

Soto-Arenas, M. A. and A. R. Solano-Gómez. 2007. Ficha técnica de Sigmatostalix guatemalensis. In: Soto-Arenas, M. A. (comp.). Información actualizada sobre las especies de orquídeas del PROYNOM-059-ECOL-2000. Instituto Chinoín, A.C., Herbario AMO. Database Sistema Nacional de Información sobre Biodiversidad (SNIB)- Comisión Nacional para el Conocimiento y Uso de la Biodiversidad (CONABIO). Project No. W029. Cd. Mx., México. http://www. conabio.gob.mx/conocimiento/ise/fichasnom/Sigmatostalixguatemalensis00.pdf (consulted February, 2017).

StatSoft, 2018. STATISTICA Features Overview. TIBCO Software Inc. http://www.statsoft.com/Products/ STATISTICA-Features (consulted May, 2018).
Thompson, K. and M. A. Davis. 2011. Why research on traits of invasive plants tells us very little. Trends in Ecology and Evolution 26(4): 155-156. DOI: https://doi.org/10.1016/j. tree.2011.01.007

Trapnell, D. W., J. L. Hamrick and J. D. Nason. 2004. Threedimensional fine-scale genetic structure of the neotropical epiphytic orchid Laelia rubescens. Molecular Ecology 13(5): 1111-1118. DOI: https://doi.org/10.1111/j.1365294X.2004.02148.x

Tremblay, R. L., J. D. Ackerman, J. K. Zimmerman and R. N. Calvo. 2005. Variation in sexual reproduction in orchids and its evolutionary consequences: a spasmodic journey to diversification. Botanical Journal of the Linnean Society 84(1): 1-54. DOI: https://doi.org/10.1111/j.10958312.2004.00400.x

USGS. 2018. U.S Geological Survey Hydro.1k. United States Geological Survey. http://usgs.gov (consulted May, 2018).

Winkler, M. and P. Hietz. 2001. Population structure of three epiphytic orchids (Lycaste aromatica, Jacquiniella leucomelana and $J$. teretifolia) in a Mexican humid montane forest. Selbyana 22(1): 27-33.

Winkler, M., K. Hülber and P. Hietz. 2009. Population dynamics of epiphytic orchids in a metapopulation context. Annals of Botany 104(5): 995-1004. DOI: https://doi. org/10.1093/aob/mcp188

WorldClim. 2017. Free climate data for ecological modeling and GIS. WorldClim-Global Climate Data. http://www. worldclim.org/ (consulted November, 2017).

Zotz, G. 1998. Demography of the epiphyte orchid, Dimerandra emarginata. Journal of Tropical Ecology 14(6): 725-741. DOI: https://doi.org/10.1017/S0266467498000534

Zotz, G. and G. Schmidt. 2006. Population decline in the epiphytic orchid Aspasia principissa. Biological Conservation 129(1): 82-90. DOI: https://doi. org/10.1016/j.biocon.2005.07.022 